\title{
Efektivitas Terapi Kompres Dingin dalam Menurunkan Stres Orang dengan Lupus (Odapus) Dewasa Muda di Perhimpunan Masyarakat Peduli Lupus Parahita Malang
}

\author{
Elvira Sari Dewi, Soemardini**, Ika Setyo Rini*
}

\begin{abstract}
ABSTRAK
Kompres dingin dapat digunakan untuk menurunkan stres. Tujuan penelitian ini adalah mengetahui efektivitas terapi kompres dingin dalam menurunkan stres Odapus dewasa muda di Parahita. Penelitian ini dilakukan dengan studi eksperimental semu menggunakan one group pretest posttest design. Sampel dipilih dengan teknik total sampling dan didapatkan 25 sampel sesuai kriteria inklusi dan kriteria eksklusi. Variabel yang diukur adalah stres sebelum dan sesudah diberikan terapi kompres dingin baik secara fisik (tekanan darah, pernapasan, nyeri kepala, dan gangguan tidur), kognitif (gangguan konsentrasi dan daya ingat), maupun emosional (tingkat stres). Hasil penelitian menunjukkan bahwa pemberian kompres dingin berpengaruh terhadap penurunan pernapasan, nyeri kepala, gangguan tidur, tingkat stres, dan gangguan konsentrasi dengan nilai $p<$ 0,05 . Namun pemberian kompres dingin tidak menunjukkan pengaruh pada penurunan tekanan darah dan gangguan daya ingat dengan nilai $p>0,05$. Dapat disimpulkan bahwa terapi kompres dingin dapat digunakan untuk menurunkan stres Odapus dewasa muda di Parahita dengan efektivitas: (1) Terapi kompres dingin dapat digunakan untuk menurunkan respons stres berupa penurunan pernapasan, nyeri kepala, gangguan tidur, tingkat stres, dan gangguan konsentrasi. (2) Terapi kompres dingin tidak dapat digunakan untuk menurunkan respons stres berupa peningkatan tekanan darah dan gangguan daya ingat.
\end{abstract}

Kata kunci: Kompres dingin, Lupus, Odapus, Parahita, Stres.

\section{Effectiveness of Cold Compress Therapy to Decrease Stress in Lupus Patient (Odapus) at Lupus Care Community Parahita Malang}

\begin{abstract}
Cold compress can be used to decrease stress. The research aimed was to know the effectiveness of cold compress therapy to decrease stress of early adult lupus patient (Odapus) at Parahita Malang. This research was done using pseudo experimental study by one group pretest posttest design. There were 25 samples that choose by total sampling technique which fulfil inclusion and exclusion criteria. The measured variable were stress before and after cold compress therapy (blood pressure, respiration, head pain, and sleep disturbance), cognitive (concentration and memory disturbance), and emotional (level of stress). The results showed that cold compress therapy can decrease respiration, head pain, sleep disturbance, level of stress, and concentration disturbance with $p$ value $<0.05$. But, cold compress therapy can not decrease blood pressure and memory disturbance with $p$ value $>0.05$. It can be concluded that cold compress therapy can decrease stress in early adult lupus patient Odapus at Parahita with effectiveness: (1) Cold compress therapy can decrease stress responses such as decreasing respiration, head pain, sleep disturbance, level of stress, and concentration disturbance. (2) Cold compress therapy can not decrease stress responses such as decreasing blood pressure and memory disturbance.
\end{abstract}

Keyword: Cold compress, Lupus, Odapus, Parahita, Stress.

* Program Studi llmu Keperawatan FKUB

**Laboratorium Faal FKU 


\section{PENDAHULUAN}

Lupus adalah penyakit autoimun kronis. ${ }^{1,2}$ Autoimun adalah kelainan pada sistem imun saat kekebalan tubuh tidak dapat membedakan jaringan tubuh sendiri dan organisme asing (misalnya bakteri atau virus). Autoimun disebabkan oleh adanya autoantibodi (antibodi yang menyerang jaringan tu-buh sendiri) yang diproduksi tubuh dalam jumlah besar dan terjadi pengendapan kompleks imun di dalam jaringan. Hal tersebut dapat membahayakan organ dan/atau sistem tubuh yang diserang. ${ }^{1,3}$ Kronis berarti tanda gejalanya lebih dari enam bulan dan biasanya terjadi bertahun-tahun. ${ }^{3,4}$

Lebih dari 5.000 .000 orang dalam usia produktif di seluruh dunia terdiagnosis Lupus. ${ }^{1}$ Angka kejadian rata-rata Lupus di seluruh Asia adalah sekitar 1-25 ke-sakitan per 100.000 penduduk. ${ }^{5}$ Belum ada angka yang pasti untuk jumlah orang dengan Lupus (Odapus) di seluruh Indonesia, namun perkiraannya adalah lebih dari 300.000 orang. ${ }^{6}$ Berdasarkan data Perhimpunan Masyarakat Peduli Lupus Parahita Malang, jumlah Odapus di kota Malang dan sekitarnya yang tercatat sebagai anggota Parahita mencapai 44 orang. Dengan kata lain, jumlah populasi penyandang Lupus di kota Malang dan seki-tarnya mencapai lebih kurang $0,00088 \%$ dari seluruh populasi pasien Lupus di dunia dan $0,01467 \%$ dari seluruh populasi pasien Lupus di Indonesia.

Dewasa muda adalah tahap tumbuh kembang antara usia 18 dan 40 tahun. ${ }^{7}$ Lebih dari $90 \%$ penyandang Lupus adalah wanita yang berusia 15 sampai 45 tahun. Dengan kata lain, mayoritas dari Odapus berada pada rentang usia dewasa muda. ${ }^{3}$

Dewasa muda umumnya aktif, produktif, dan minimum terkena masalah kesehatan utama. ${ }^{7}$ Namun kenyataan yang dihadapi oleh Odapus berbeda dengan harapannya. Di saat dewasa muda pada umumnya mulai bekerja, memilih pasangan, mulai membina keluarga, mengasuh anak, dan mengelola rumah tangga, Odapus harus menghadapi kondisi keterbatasaan fisik yang dapat menghambat tugas perkembangannya. Hal ini dapat menjadi stresor (penyebab stres) tersendiri bagi Odapus. ${ }^{3,7}$

Odapus akan dihadapkan dengan stresor fisik maupun stresor psikologis setiap harinya. Stresor fisik meliputi kerentanan tubuhnya terhadap kelelahan fisik, kerentanan terhadap stres, kerentanan terhadap paparan sinar matahari yang berlebihan, konsumsi obat terusmenerus, kondisi fisik yang naik turun, fatigue atau kelelahan, dan produktivitas yang menurun. Stresor psikologis meliputi lamanya pencarian diagnosis yang tepat, kenyataan yang harus dihadapi setelah didiagnosis Lupus, respons keluarga akan penyakitnya, kekhawatiran akan masa depan, perasaan yang berat, perasaan tidak dapat mengontrol hidup, marah, depresi, dan berduka. Hal tersebut dapat menyebabkan situasi penuh ketegangan atau stres yang terus menerus dan berkepanjangan. ${ }^{37}$

Stres yang terus menerus dan berkepanjangan dapat membahayakan kondisi Odapus. Stres dapat menyebabkan kekambuhan. Stres juga dapat memperparah kondisi penyakit Lupus. Oleh karena itu, diperlukan cara untuk menurunkan stres yang dihadapi Odapus agar kekambuhan tidak terjadi dan kualitas hidup pasien Lupus dapat ditingkatkan. 3,8

Dewasa ini, banyak sekali terapi yang digunakan untuk menurunkan stres, misalnya dengan terapi humor, visualisasi, yoga, meditasi, akupuntur, rekreasi ke pegunungan, atau bahkan dengan terapi-terapi yang sifatnya farmakologis yang dapat menimbulkan efek samping. Tidak semua Odapus memiliki selera humor yang tinggi dan tidak semua Odapus mempunyai uang lebih untuk mendapatkan terapi-terapi yang dibutuhkan sehingga ditemukan cara yang mudah dan murah untuk menurunkan stres yang dihadapi Odapus yaitu dengan terapi kompres dingin. 8,9 
Kompres dingin dapat digunakan sebagai terapi untuk menurunkan stres pada Odapus dewasa muda. ${ }^{8}$ Suhu sejuk dari kompres dingin mempunyai efek lokal memvasokonstriksi, menurunkan permeabilitas kapiler, merelaksasi otot, dan menurunkan suhu prefrontral korteks di otak sehingga dapat dimanfaatkan untuk mengurangi rasa nyeri kepala, mengurangi respons fisiologis, meningkatkan fungsi kognitif, dan menurunkan tekanan darah Odapus dewasa muda yang sedang mengalami stres. Namun masih diperlukan penelitian lebih lanjut untuk membuktikan keefektifan terapi kompres dingin pada Odapus agar didapatkan hasil yang maksimal dan kualitas hidup pasien Lupus di Indonesia dapat ditingkatkan. $8,10,11$

Berdasarkan latar belakang tersebut, penulis ingin membuktikan keefektifan terapi kompres dingin dalam menurunkan stres pada Odapus dewasa muda di Perhimpunan Masyarakat Peduli Lupus Parahita Malang.

Tujuan penelitian ini untuk mengetahui pengaruh kompres dingin terhadap penurunan stres orang dengan Lupus (Odapus) dewasa muda di Perhimpunan Masyarakat Peduli Lupus Parahita Malang.

\section{BAHAN DAN METODE}

Penelitian ini dilakukan pada Odapus dewasa muda di Parahita Malang dan di rumah masing-masing anggota Parahita menggunakan studi eksperimental semu dengan desain one group pretest posttest. Sampel dipilih dengan teknik total sampling dan didapatkan 25 sampel yang sesuai kriteria inklusi dan kriteria eksklusi.

Kriteria inklusi meliputi: pasien dengan Lupus, tercatat sebagai anggota Parahita, usia 18-40 tahun, mengalami stres (secara fisik atau kognitif atau emosional), bersedia menjadi subjek penelitian, bisa membaca dan menulis, bisa menyadari rasa dingin dan membedakan suhu yang terlalu dingin untuk jaringan tubuh, bisa menoleransi dingin dengan baik, status kesadaran penuh dan kondisi umum baik, serta mempunyai lemari es di rumahnya. Sementara kriteria eksklusi meliputi: alergi dingin, adanya luka terbuka pada daerah yang akan dikompres (dahi dan kulit kepala), gangguan sirkulasi, sindrom Raynaud pada Lupus.

Variabel yang diukur adalah stres sebelum dan sesudah diberikan terapi kompres dingin baik secara fisik (tekanan darah, pernapasan, nyeri kepala, dan gangguan tidur), kognitif (gangguan konsentrasi dan daya ingat), maupun emosional (tingkat stres).

Masing-masing sampel dalam penelitian ini diberi instrument penelitian yaitu: 1 leaflet; 1 informed consent; 1 alat kompres dingin yang digunakan sebagai alat terapi., 8,13 Selain, itu diberikan juga 2 kuesioner pengukur stres yang merupakan modifikasi dari kuesioner Depression anxiety and Stress Scales (DASS), ${ }^{12}$ pengukuran biophysical oleh penulis, serta persepsi pasien terhadap Lupusnya, dan 1 format pelaksanaan pemberian kompres dingin. Masing-masing sampel diberikan pelatihan penggunaan kompres dingin di rumah maing-masing dan diukur stresnya terlebih dahulu. Pada minggu berikutnya penulis kembali melakukan pengukuran stress pada sampel sesudah diberikan terapi kompres dingin.

\section{Pembuatan Alat Kompres Dingin}

Alat kompres dingin dibuat dengan bahan-bahan berikut: $1 \mathrm{sdm}$ air cuka, $3 \mathrm{sdm}$ tepung kanji, dan $400 \mathrm{ml}$ air. Sebanyak $3 \mathrm{sdm}$ tepung kanji, $1 \mathrm{sdm}$ air cuka, dan $400 \mathrm{ml}$ air dimasukkan ke dalam panci dan diaduk sampai adonan tercampur rata. Adonan direbus sampai mendidih sambil diaduk. Adonan dibiarkan di udara terbuka. Setelah dingin adonan dimasukkan ke kantong plastik ukuran $1 \mathrm{~kg}$. Usahakan tidak ada udara di dalam plastik. Rekatkan plastik dengan menggunakan api dan lilin. Simpan di dalam lemari es dengan suhu $18-27{ }^{\circ} \mathrm{C}$ (Gambar 1).8,13 Apabila akan digunakan, 
bungkus dengan kain agar lebih nyaman jika dipakai di kepala.

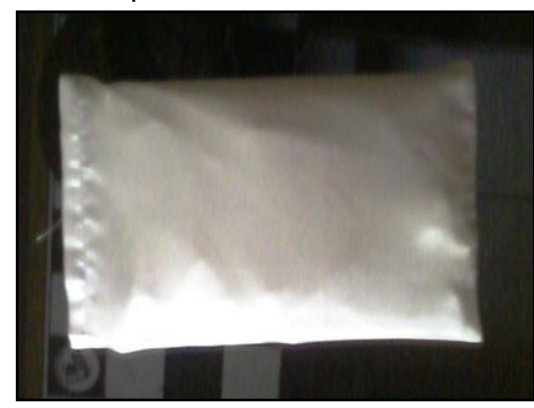

Gambar 1. Alat kompres dingin untuk menurunkan stres orang dengan Lupus (Odapus) dewasa muda di Perhimpunan Masyarakat Peduli Lupus Parahita Malang.

\section{Penerapan Terapi Kompres Dingin}

Keluarga atau teman yang serumah dengan Odapus mempersiapkan pemberian kompres dingin pada saat pasien akan tidur malam dengan terlebih dahulu mencuci tangan. Mereka mengkaji apakah pasien dapat menyadari rasa dingin serta dapat membedakan suhu yang terlalu dingin untuk jaringan tubuh serta tingkat kesadaran dan kondisi umum pasien. Pasien yang sangat muda, sangat tua, tidak sadar, atau yang lemah tidak dapat menoleransi dingin dengan baik.

Keluarga atau teman yang serumah dengan Odapus memastikan bahwa tidak ada luka, memar, perdarahan, warna pucat atau kebiruan, suhu, dan kurangnya sensasi atau mati rasa pada dahi dan kulit kepala pasien.

Mereka juga memastikan bahwa pasien tidak mempunyai alergi dingin dan fenomena Raynaud.

Keluarga atau teman yang serumah dengan Odapus memberikan privasi pada pasien, memajankan area yang akan dikompres, dan memberikan kehangatan untuk menghindari pasien menggigil. Mereka juga menyiapkan pasien dan membantu pasien ke posisi yang nyaman. Teraoi kompres dingin dilakukan di dahi dan kulit kepala selama 20 menit sebelum tidur dengan posisi yang tidak berubah-ubah.
Apabila terjadi ketidaknyamanan atau terjadi reaksi tidak baik seperti penampilan yang pucat dan berbintik-bintik kompres, maka segera meghubungi penulis. Lalu segera melepaskan alat kompres setelah 20 menit guna menghindari fenomena rebound dan efek yang membahayakan dari kompres dingin yang berkepanjangan. Alat kompres dingin yang telah digunakan disimpan dalam lemari es.

Selama proses terapi berlangsung, respons pasien dicatat pada lembar kuisioner. Prosedur pemberian kompres dingin dilakukan selama satu minggu berturut-turut sesuai dengan panduan. ${ }^{10,12}$

Data yang telah didapat dianalisis secara statistik univariat (deskriptif) dan bivariat (uji Wilcoxon). Analisis statistik univariat (deskriptif) digunakan untuk menganalisis data stres Odapus sebelum dan sesudah diberikan terapi kompres dingin. Sementara analisis statistik bivariat (Wilcoxon) digunakan untuk menguji pengaruh terapi kompres dingin terhadap penurunan stres menggunakan SPSS 16.0 for Windows dengan tingkat kepercayaan sebesar $95 \%$ dan tingkat kesalahan (a) sebesar 0,05.

\section{HASIL}

Berdasarkan 25 sampel yang diteliti, 14 sampel (56\%) bertempat tinggal di wilayah kota Malang dan 11 sampel (44 \%) bertempat tinggal di luar kota Malang.

Analisis statistik univariat pada data stres sebelum dan sesudah diberikan terapi kompres dingin disajikan pada Tabel 1.

Tabel 1. Respons stres odapus dewasa muda di Parahita sebelum dan sesudah diberikan terapi kompres dingin.

\begin{tabular}{lcrrc}
\hline Respons stres & $\begin{array}{c}\text { Pre } \\
\text { test } \\
\text { Tekanan darah }\end{array}$ & $\begin{array}{c}\text { Post } \\
\text { test }\end{array}$ & $\%$ \\
\hline Normal & 13 & 52 & 14 & 56 \\
Prehipertensi & 12 & 48 & 11 & 44 \\
\hline \multicolumn{5}{c}{ Pernapasan } \\
\hline
\end{tabular}




\begin{tabular}{|c|c|c|c|c|}
\hline Normal & 17 & 68 & 24 & 96 \\
\hline Meningkat & 8 & 32 & 1 & 4 \\
\hline \multicolumn{5}{|c|}{ Nyeri kepala } \\
\hline Tidak ada & 10 & 40 & 23 & 92 \\
\hline Tingkat ringan & 7 & 28 & 2 & 8 \\
\hline Tingkat sedang & 4 & 16 & 0 & 0 \\
\hline Tingkat berat & 4 & 16 & 0 & 0 \\
\hline $\begin{array}{l}\text { Tingkat sangat } \\
\text { berat }\end{array}$ & 0 & 0 & 0 & 0 \\
\hline \multicolumn{5}{|c|}{ Gangguan tidur } \\
\hline Tidak ada & 8 & 32 & 23 & 92 \\
\hline Ada & 17 & 68 & 2 & 8 \\
\hline \multicolumn{5}{|c|}{ Gangguan konsentrasi } \\
\hline Tidak ada & 14 & 56 & 23 & 84 \\
\hline Ada & 11 & 44 & 4 & 16 \\
\hline \multicolumn{5}{|c|}{ Gangguan daya ingat } \\
\hline Tidak ada & 13 & 52 & 18 & 72 \\
\hline Ada & 12 & 48 & 7 & 28 \\
\hline \multicolumn{5}{|c|}{ Tingkat stres } \\
\hline Normal & 9 & 36 & 21 & 84 \\
\hline Ringan & 5 & 20 & 3 & 12 \\
\hline Sedang & 9 & 36 & 1 & 4 \\
\hline Berat & 0 & 0 & 0 & 0 \\
\hline Sangat berat & 2 & 8 & 0 & 0 \\
\hline
\end{tabular}

Untuk mengetahui pengaruh pemberian terapi kompres dingin terhadap penurunan stres odapus dewasa muda di Parahita. Maka dilakukan analisis data pada Tabel 1 menggunakan uji Wilcoxon dengan $a=0,05$ didapatkan nilai signifikansi $(p)$ yang ditampilkan pada Tabel 2 berikut ini.

Tabel 2. Pengaruh pemberian terapi kompres dingin terhadap penurunan stres Odapus berdasarkan $p$-value.

\begin{tabular}{|c|c|c|}
\hline Respons Stres & $\begin{array}{c}\mathrm{p}- \\
\text { value }\end{array}$ & Keterangan \\
\hline Tekanan darah & 0,655 & $\begin{array}{l}\text { Terapi kompres } \\
\text { dingin tidak dapat } \\
\text { digunakan untuk } \\
\text { menurunkan tekanan } \\
\text { darah yang } \\
\text { meningkat }\end{array}$ \\
\hline Pernapasan & 0,008 & $\begin{array}{l}\text { Terapi kompres } \\
\text { dingin dapat } \\
\text { digunakan untuk } \\
\text { menurunkan } \\
\text { pernapasan yang } \\
\text { meningkat }\end{array}$ \\
\hline Nyeri kepala & 0,001 & $\begin{array}{l}\text { Terapi kompres } \\
\text { dingin dapat }\end{array}$ \\
\hline
\end{tabular}

\begin{tabular}{|c|c|c|}
\hline & & $\begin{array}{l}\text { digunakan untuk } \\
\text { menurunkan nyeri } \\
\text { kepala }\end{array}$ \\
\hline Gangguan tidur & 0,000 & $\begin{array}{l}\text { Terapi kompres } \\
\text { dingin dapat } \\
\text { digunakan untuk } \\
\text { menurunkan } \\
\text { gangguan tidur }\end{array}$ \\
\hline $\begin{array}{l}\text { Gangguan } \\
\text { konsentrasi }\end{array}$ & 0,020 & $\begin{array}{l}\text { Terapi kompres } \\
\text { dingin dapat } \\
\text { digunakan untuk } \\
\text { menurunkan } \\
\text { gangguan konsentras }\end{array}$ \\
\hline $\begin{array}{l}\text { Gangguan } \\
\text { daya ingat }\end{array}$ & 0,059 & $\begin{array}{l}\text { Terapi kompres } \\
\text { dingin tidak dapat } \\
\text { digunakan untuk } \\
\text { menurunkan } \\
\text { gangguan daya ingat }\end{array}$ \\
\hline Tingkat stres & 0,000 & $\begin{array}{l}\text { Terapi kompres } \\
\text { dingin dapat } \\
\text { digunakan untuk } \\
\text { menurunkan tingkat } \\
\text { stres }\end{array}$ \\
\hline
\end{tabular}

\section{PEMBAHASAN}

Kompres dingin dapat digunakan sebagai terapi untuk menurunkan stres pada Odapus rentang usia dewasa muda. ${ }^{8}$ Berdasarkan pada pendapat tersebut, maka peneliti melakukan studi eksperimental semu pada Odapus dewasa muda di Parahita. Alasan dipilihnya studi eksperimental semu dalam penelitian ini adalah respons stres tiap-tiap orang tidaklah sama dan keterbatasan penulis yang tidak dapat mengontrol koping masing-masing individu dalam menghadapi stresnya.

Masing-masing orang mempunyai cara tersendiri dalam menghadapi stresornya. Hal tersebut didukung oleh pernyataan Odapus tentang persepsi pasien terhadap Lupus. Ada pasien yang menanggapi dengan "santai saja", "memang sudah takdirnya", "pasti ada hikmahnya", "Tuhan punya rencana lain dan banyak yang harus disyukuri", "capek", "berpikiran tidak punya penyakit supaya tidak sedih", dan sebagainya. Semua cara tersebut merupakan persepsi dan koping pasien yang tidak dapat diseragamkan karena apabila diseragamkan dapat menjadi stresor tersendiri bagi Odapus. Apabila stres terjadi 
pada Odapus, regulasi sistem imun akan kacau, respons imun meningkat berlebihan, dan kekambuhan Lupus dapat terjadi, sehingga dapat membahayakan Odapus. ${ }^{14}$

Dari 44 pasien yang dihubungi hanya diperoleh 25 pasien yang memenuhi kriteria inklusi dan kriteria eksklusi. Sebanyak 14 sampel (56 \%) bertempat tinggal di wilayah kota Malang dan 11 sampel (44\%) bertempat tinggal di luar kota Malang. Hal ini membutuhkan waktu yang cukup panjang dan tenaga lebih untuk mencapai daerah-daerah tersebut.

Teknik door to door dipilih karena penulis menyesuaikan dengan kondisi pasien yang sering mengalami remisi (hilang) dan eksaserbasi (timbul) selama menderita penyakit Lupus dan diharapkan dapat meminimalkan risiko gangguan keselamatan pada pasien selama berlangsungnya penelitian..$^{1,21}$

Dalam waktu satu minggu masingmasing sampel mempraktikkan terapi kompres dingin sesuai dengan panduan yang ada pada format pelaksanaan pemberian kompres dingin. Selama penelitian, tidak ada laporan dari Odapus mengenai efek samping terapi yang terjadi padanya. Secara umum, laporan kuisioner meliputi pengalaman Odapus menggunakan kompres dingin berdasarkan data dokumentasi respons pasien.

Namun, tidak semua sampel mendokumentasikan responsnya terhadap kompres dingin. Beberapa sampel menyatakan bahwa kompres dingin dapat menyebabkan cepat tidur dan pulas sehingga sampel tidak minum obat tidur lagi. Hal ini sesuai dengan penelitian sebelumnya bahwa suhu dingin yang dimiliki kompres dingin dapat digunakan untuk menurunkan suhu prefrontal korteks di otak sehingga mendorong seseorang untuk istirahat dan tidur lebih awal. ${ }^{11}$

Sementara itu, tiga sampel lain menyatakan tidak tahan dengan durasi 20 menit pemberian kompres dingin pada awal terapi, sehingga kompres dingin hanya digunakan selama 5 menit. Pada hari ketiga dan seterusnya kompres dingin digunakan selama 20 menit. Ada dua kemungkinan yang menyebabkan sampel tidak tahan menggunakan kompres dingin selama 20 menit. Pertama, sampel masih dalam masa adaptasi dan yang kedua suhu lemari es terlalu dingin. Suhu yang digunakan untuk terapi kompres dingin adalah suhu sejuk (18$27{ }^{\circ} \mathrm{C}$ ) dan tidak boleh $<15^{\circ} \mathrm{C}$ karena proses vasokonstriksi maksimal terjadi ketika kulit yang dikompres mencapai suhu $15{ }^{\circ} \mathrm{C}$. Pada suhu di bawah $15{ }^{\circ} \mathrm{C}$ vasodilatasi akan terjadi. Kondisi inilah yang dimaksud dengan fenomena Rebound yakni kondisi yang terjadi pada saat efek terapeutik dari kompres dingin telah dicapai dan kemudian efek yang berlawanan terjadi sehingga pasien akan merasakan sakit kepala. ${ }^{10}$

Dokumentasi satu, sampel menyatakan bahwa alat kompresnya bau busuk dan amis (ikan bercampur daging) saat digunakan di kepala sehingga sampel merasa tidak nyaman, selain itu juga sudah mencair dan tidak berupa jeli. Hal ini karena sampel yang tidak pernah menyimpan alat kompres di lemari es setelah penggunaan. Alat kompres dibiarkan di udara terbuka dan dimasukkan ke dalam lemari es dua jam sebelum tidur malam di tempat penyimpanan ikan. Alat kompres seharusnya dimasukkan ke dalam lemari es dengan dibungkus tas kresek dan tidak dicampur dengan ikan atau daging, agar lebih awet, tidak busuk, dan tidak berbau amis.

Untuk ke depannya, bau amis ikan bercampur daging tersebut dapat disubtitusi dengan aroma terapi, sehingga efek kompres dinginnya dalam menurunkan stres diharapkan akan lebih efektif, mengingat aroma terapi juga merupakan salah satu bentuk terapi stres. ${ }^{19}$

Dokumentasi dua, sampel menyatakan mengalami pilek pada awal pemakaian terapi, walaupun mereka tidak memiliki alergi dingin. Ada banyak kemungkinan yang 
menyebabkan pasien pilek, bisa jadi pasien alergi atau kekebalan tubuhnya sedang kurang baik. ${ }^{20}$

Dokumentasi selanjutnya, sampel menyatakan bahwa terapi kompres dingin lebih terasa efeknya apabila digunakan langsung pada saat penat di siang hari, karena pada saat malam sebelum tidur lebih cenderung tertidur dan lupa dengan stresnya. Pemberian terapi kompres dingin diharapkan dapat membuat tidur lebih awal, yang dapat menurunkan kadar kortisol, epinefrin, dan norepinefrin yang meningkat pada saat stres, sehingga respons stres bisa diturunkan. Kompres dingin juga mempunyai efek lokal vasokonstriksi, pada saat penat di siang hari, pembuluh darah yang sedang mengalami dilatasi dapat dikonstriksikan dengan terapi ini.

Hasil pengolahan dan analisis data menunjukkan bahwa terapi kompres dingin dapat digunakan untuk menurunkan respons stres yang berupa peningkatan pernapasan, nyeri kepala, gangguan tidur, gangguan konsentrasi, dan tingkat stres. Namun, respons stres yang berupa peningkatan tekanan darah dan gangguan daya ingat dalam penelitian ini tidak dapat diturunkan dengan terapi kompres dingin.

Pada saat stres, kadar CRH/CRF meningkat berlebihan sehingga menimbulkan vasodilatasi dan meningkatkan permeabilitas kapiler di otak. ${ }^{15}$ Efek kompres dingin yang bekerja lokal dapat melakukan vasokonstriksi dan menurunkan permeabilitas kapiler di otak sehingga nyeri kepala dapat dikurangi. ${ }^{10}$ Pemberian kompres dingin berpengaruh terhadap penurunan nyeri kepala Odapus dewasa muda di Parahita $(p<0,05)$. Hal tersebut menunjukkan perbedaan yang bermakna sebelum dan sesudah pemberian terapi kompres dingin dalam menurunkan nyeri kepala.

Selain itu, kompres dingin juga dapat dimanfaatkan untuk menurunkan suhu prefrontal korteks di otak sehingga mendorong seseorang untuk istirahat dan tidur lebih awal. ${ }^{11}$ Penelitian ini menunjukkan bahwa terapi kompres dingin secara bermakna menurunkan gangguan tidur (sulit tidur) pada Odapus ( $p=0,000 ; p<0,05$ ).

Pada saat tidur, kadar norepinefrin seseorang akan menurun sehingga respons e-mosional yang berlebihan, fungsi rasional yang menurun, dan peningkatan tekanan darah akibat stres dapat diperbaiki. ${ }^{7}$

Hasil penelitian menunjukkan bahwa kompres dingin tidak dapat digunakan untuk menurunkan tekanan darah Odapus yang sedang mengalami stres $(p=0,655 ; p<$ $0,05)$. Hal ini karena tidak semua Odapus mengalami peningkatan tekanan darah pada saat stres, sehingga diperlukan lebih banyak responden yang mengalami peningkatan tekanan darah agar hasilnya bisa memuaskan. Selain itu, peningkatan tekanan darah tidak hanya disebabkan oleh pelepasan norepinefrin yang berlebihan pada sistem kardiovaskuler. Epinefrin juga ikut dilepaskan berlebihan bersama norepinefrin pada sistem kardiovaskuler sehingga dapat menyebabkan peningkatan tekanan darah pada saat stres. ${ }^{16}$ Efek kompres dingin yang menyebabkan seseorang cepat tidur hanya dapat menurunkan kadar norepinefrin. ${ }^{7}$ Apabila dihubungkan dengan hasil penelitian ini, kadar norepinefrin turun dengan kompres dingin, namun kadar epinefrin tetap. Jadi, kompres dingin tidak da-pat digunakan untuk menurunkan tekanan darah Odapus yang meningkat pada saat stres.

Pada saat stres pernapasan Odapus meningkat. Hal tersebut disebabkan oleh peningkatan kadar norepinefrin. ${ }^{14}$ Dalam penelitian ini kadar norepinefrin yang meningkat dapat diturunkan secara nyata dengan pemberian kompres dingin $(p=0,008$ $; p<0,05)$. Dengan kata lain, kompres dingin dapat digunakan untuk menurunkan pernapasan yang meningkat pada saat stres.

Tidur penting sekali untuk memori dan konsentrasi. $^{7}$ Hasil penelitian menunjukkan bahwa terapi kompres dingin dapat menurunkan gangguan konsentrasi $(p=$ 
$0,020 ; p<0,05)$. Dapat disimpulkan bahwa terapi kompres dingin dapat digunakan untuk menurunkan gangguan konsentrasi atau meningkatkan konsentrasi.

Terapi kompres dingin pada Odapus tidak dapat digunakan untuk menurunkan gangguan memori atau daya ingat $(p=0,059$; $p>0,05$ ). Persentase gangguan daya ingat (sering lupa) pada sampel yang diteliti sebelum diberikan terapi kompres dingin lebih besar (49\%) dibandingkan dengan sesudah diberikan terapi kompres dingin (28\%). Hal ini menunjukkan bahwa ada pengaruh pemberian terapi kompres dingin terhadap penurunan gangguan daya ingat, tetapi tidak memenuhi syarat untuk keefektifannya. Adanya gangguan daya ingat pada Odapus dewasa muda di Parahita tidak hanya disebabkan oleh peningkatan kadar norepinefrin yang berlebihan pada saat stres, namun bisa juga disebabkan oleh manifestasi Lupus yang berupa gangguan kognitif. ${ }^{1-2-3}$ Bisa jadi pada saat penelitian, sampel/pasien sedang mengalami eksaserbasi, sehingga pemberian terapi kompres dingin tidak dapat digunakan untuk menurunkan gangguan daya ingat pada saat stres.

Tidur lebih awal dapat menurunkan kadar kortisol sebesar $50 \%$. Jika kadar kortisol tidak terlalu tinggi, respons stres dapat dikurangi dan pasien Lupus dapat lebih tenang. ${ }^{17}$ Teori tersebut didukung oleh hasil penelitian yang menunjukkan bahwa terapi kompres dingin dapat menurunkan tingkat stres secara secara nyata $(p=0,000 ; p<$ $0,05)$. Hal ini menunjukkan bahwa teradapat perbedaan yang bermakna pada tingkat stres sebelum dan sesudah diberikan terapi kompres dingin.

\section{IMPLIKASI PENELITIAN UNTUK DUNIA KEPERAWATAN}

1. Hasil penelitian menunjukkan bahwa efek terapi kompres dingin dapat digunakan untuk menurunkan stres pada Odapus dewasa muda di Parahita ini dapat digunakan sebagai dasar ilmu dan praktik dalam menurunkan demam, nyeri, dan insomnia, kompres dingin juga dapat digunakan untuk menurunkan stres. Hal tersebut menambah referensi tentang terapi yang dapat diberikan perawat kepada pasiennya, khususnya kepada pasien Lupus yang mengalami stres.

2. Hasil penelitian ini dapat digunakan sebagai referensi tentang integrasi beberapa ilmu keperawatan yang meliputi ilmu keperawatan dasar (kompres dingin), ilmu keperawatan jiwa (stres), ilmu keperawatan medikal bedah (imunologi), dan psychoneuro-immunology (hubungan antara stres dan penyakit Lupus). Harapannya ilmu keperawatan semakin berkembang dan banyak penelitian keperawatan yang menjadikan penelitian ini semakin sempurna.

3. Dalam merawat pasien Lupus dengan stres perlu diperhatikan bahwa stres dapat menyebabkan kekambuhan atau dapat memperparah penyakit Lupus sehingga perlu diminimalkan adanya stresor pada Odapus. Namun tidak semua pasien dapat diberikan terapi kompres dingin, beberapa pasien ada yang mempunyai alergi terhadap dingin dan ada juga yang mempunyai manifestasi Lupus berupa fenomena Raynaud.

4. Stres tidak hanya terjadi pada Odapus, semua pasien yang terpapar dengan stresor akan menunjukkan respons (baik fisik, kognitif, maupun emosional) yang disebut dengan stres. Sehingga untuk pelaksanaan ke depannya, alat kompres ini juga bisa diberikan perawat kepada pasien non-Odapus yang mengalami stres.

5. Dengan menerapkan hasil penelitian ini secara efektif pada dunia praktik keperawatan diharapkan kualitas pelayanan keperawatan dapat ditingkatkan. 


\section{KETERBATASAN PENELITIAN}

1. Desain yang digunakan dalam penelitian ini adalah eksperimental semu sehingga penulis tidak dapat mengontrol jalannya penelitian secara ketat. Hal-hal yang tidak dapat dikontrol oleh penulis meliputi: stresor yang dihadapi individu saat berlangsungnya penelitian, respons stres masing-masing individu, dan cara individu dalam mengoping stresnya. Apabila halhal tersebut dikontrol dan diseragamkan pada semua sampel, bisa jadi menimbulkan stresor tersendiri dan membahayakan Odapus.

2. Proses pengambilan data dilakukan oleh penulis sendiri sehingga data-data yang diperoleh dapat diukur dengan standar yang sama. Namun pelaksanaan pemberian kompres dingin didelegasikan kepada pasien dan keluarga karena keterbatasan waktu yang dimiliki oleh penulis. Sehingga penulis tidak dapat mengontrol langsung jalannya penelitian kecuali dengan hasil format pelaksanaan pemberian kompres dingin dan dokumentasi respons pasien selama pemberian kompres dingin yang telah diisikan oleh sampel penelitian.

3. Belum ada kuesioner yang baku untuk mengukur stres secara keseluruhan (fisik, kognitif, dan emosional) sehingga pengolahan dan analisis data dalam penelitian ini dirasa kurang praktis dengan tujuh respons stres yang diukur, diolah, dan dianalisis satu per satu. Hal tersebut dapat memakan banyak waktu, tenaga, dan pikiran.

4. Pengambilan data untuk gangguan tidur, gangguan konsentrasi, dan gangguan daya ingat dalam penelitian ini dirasa kurang memuaskan karena hanya digunakan pernyataan "ya" dan "tidak" dari sampel.

5. Ada tiga sampel yang tidak tahan dengan dinginnya kompres pada tiga hari pertama pemakaian sehingga hal tersebut dapat mempengaruhi efek yang dihasilkan dalam pengukuran stres sesudah pemberian terapi kompres dingin.

6. Tidak ditemukan rumus untuk mencari jumlah sampel minimal dalam penelitian ini karena belum ada penelitian tentang pengaruh terapi kompres dingin terhadap penurunan stres pada Odapus sebelumnya.

7. Belum ada sumber dan penelitian sebelumnya yang menjelaskan frekuensi dan durasi dari efek terapi kompres dingin ini terhadap penurunan stres sehingga dalam penelitian ini terapi kompres dingin diberikan setiap sebelum tidur selama satu minggu berturut-turut dengan alasan kuesioner DASS menggambarkan responss stres secara emosional selama satu minggu terakhir.

\section{KESIMPULAN}

Terapi kompres dingin terbukti dapat digunakan untuk menurunkan stres Orang dengan Lupus (Odapus) dewasa muda di Perhimpunan Masyarakat Peduli Lupus Parahita Malang secara aman, tanpa efek samping, murah, dan mudah digunakan dengan efekti-vitas sebagai berikut:

1. Terapi kompres dingin dapat digunakan untuk menurunkan respons stres yang berupa peningkatan pernapasan, nyeri kepala, gangguan tidur, gangguan konsentrasi, dan tingkat stres.

2. Terapi kompres dingin tidak dapat digunakan untuk menurunkan resons stres yang berupa peningkatan tekanan darah dan gangguan daya ingat.

\section{SARAN}

1. Terapi kompres dingin terbukti efektif, sehingga diharapkan seluruh Odapus di Indonesia, khususnya di Parahita, dapat mengaplikasikannya setiap hari sebelum tidur agar diperoleh hasil yang maksimal yaitu stres dapat diturunkan dan 
kekambuhan Lupus dapat diminimalkan sehingga kualitas pasien Lupus di seluruh Indonesia dapat ditingkatkan.

2. Agar kompres dingin ini dapat diaplikasikan untuk menurunkan stres pada Odapus di seluruh Indonesia, penulis memerlukan kerja sama dari berbagai pihak, antara lain:

a. Universitas Brawijaya, Parahita, Syamsi Dhuha Foundation (SDF), Yayasan Lupus Indonesia (YLI), pemerhati Lupus, dan pemerintah Indonesia untuk mensosialisasikan terapi kompres dingin ini pada Odapus di seluruh Indonesia melalui seminar atau media internet.

b. Perawat untuk membantu mengaplikasikan terapi kompres dingin ini pada pasien Lupus dan memberi edukasi kepada pasien dan keluarga.

c. Keluarga Odapus untuk membantu pasien dan perawat dalam mengaplikasikan terapi kompres dingin ini di rumah secara mandiri.

3. Perlu diperhatikan cara penyimpanan alat kompresnya agar bisa bertahan lama.

4. Apabila alat kompres ini dipadukan dengan aroma terapi (misalnya memberikan pewangi pada kain pembungkusnya) diharapkan bisa menghasilkan efek yang lebih maksimal untuk menurunkan stres.

5. Diharapkan ada penelitian lebih lanjut dari keperawatan mengenai terapi kompres dingin ini dengan desain yang lebih terkontrol dan menggunakan alat ukur stres (fisik, kognitif, dan emosional) secara keseluruhan agar didapatkan hasil yang lebih sempurna sehingga dapat meningkatkan kualitas dan kuantitas riset keperawatan.

6. Diperlukan penelitian lebih lanjut untuk mengetahui durasi dan frekuensi paling efektif dalam pemberian terapi kompres dingin.
7. Pasien non-Odapus yang mengalami stres mungkin bisa juga mencoba keefektifan dari terapi kompres dingin ini.

8. Perlu dikembangkan penelitian lebih lanjut mengenai efek terapi kompres dingin dalam meningkatkan konsentrasi pada pelajar/mahasiswa dengan alat ukur yang lebih memuaskan.

\section{DAFTAR PUSTAKA}

1. [SDF] Syamsi Dhuha Foundation. Lupus dan Penatalaksanaannya. (Online). 2011.http://www.research.ui.ac.id/v1/ima ges/stories/lupus/Lupus\%20dan\%20pen $\begin{array}{lll}\text { atalaksanaannya.pdf } & \text { Diakses } 8\end{array}$ November 2011.

2. Stoppard M. Panduan Kesehatan Keluarga. Winardini, DTW (Penerjemah). Jakarta: Penerbit Erlangga. 2010. HIm. 324-325.

3. [HHS\} Departement of Health and Human Services of US. Lupus. (Online). 2011.http://www.womenshealth.gov/publ ications/our-

publications/factsheet/lupus.pdf. Diakses 10 Oktober 2011.

4. Herdman TH. Nanda International Nursing Diagnoses: Definitions \& Classification 2009-2011. USA: Sheridan Books, Inc. 2009. P. 355.

5. Pons-Estel GJ, Alarcon GS, \& Scofield L. Understanding the Epidemiology and Progression of Systemic Lupus Erythematosus. Semin Arthritis Rheum. 2010; 39:257.

6. Gunadi R. Siaran pers Care for Lupus SDF Awards 2011. Penghargaan untuk Dorong Penelitian Terapi Lupus. (Online).2011.http://www.syamsidhuhafo undation.org/detailarticle-siaran-perscare-for-lupus-sdf-awards-2011-article. Diakses 25 Februari 2012.

7. Potter PA, Perry AG. Buku Ajar Fundamental Keperawatan: Konsep, Proses, dan Praktik. Edisi 4. Volume 1. Yasmin A, Made S, Dian E, Laily M, 
Ellen $\mathrm{P}$, Kusrini, SK, dan Enie $\mathrm{N}$ (Penerjemah). Jakarta: EGC. 2005. HIm. 476-494, 704-723.

8. Dewi ES, Wibawani L, Sari WR. Es Pocong: Aplikasi Terapi Kompres Dingin untuk Menurunkan Respons Stres Tingkat Berat pada Odapus Rentang Usia Dewasa Muda. PKM-GT. Tidak diterbitkan. Malang: Universitas Brawijaya. 2012.

9. Wilkinson G. Seri Kesehatan Bimbingan Dokter pada Stres. Jakarta: Dian Rakyat. 2002. HIm. 81-89.

10. Berman A, Snyder SJ, Kozier B, Erb G. Buku Ajar Praktik Keperawatan Klinis Kozier \& Erb. Edisi 5. Eny M, Esty W, Devi $Y$ (Penerjemah). Jakarta: EGC. 2009. HIm. 402-412, 420.

11. [AASM] American Academy of Sleep Medicine. Cooling the Brain during Sleep May Be an Easy, Natural and Effective Treatment for Insomnia. (Online).2011.http://www.aasmnet.org/ar ticles. aspx?id=2322. Diakses 30 Maret 2012.

12. Psychology Foundation of Australia. Depression Anxiety Stress Scale (DASS). (Online). 2011. http://www2.psy.unsw.edu.au/groups/da ss/. Diakses 26 Februari 2012.

13. Yuyun. Kursus Memasak lbu Yuyun. Makalah disajikan dalam Kursus Memasak lbu Yuyun yang Disponsori Koran Kompas. 2011.

14. Speert D. Brain Facts: A Primer on the Brain and Nervous System. $6^{\text {th }}$ Edition. Washington DC: Society for Neuroscience. 2008. P. 31-33.

15. Theoharides TC. Migraine Headaches: the Immunologist's View. Hospital Chronicles 2008; 3(4):167-171.

16. Sutikno. Hormon Epinefrin (Adrenalin). (Online).2009.http://sutikno.blog.uns.ac.i d/2009/04/05/hrmon-epinefrinadrenalin/. Diakses 13 Februari 2012.

17. Tarigan, I. Enam Cara Kurangi Hormon Stres.(Online).2010.http://www.mediaind onesia.com/mediahidupsehat/index.php/ read/2010/01/01/2098/4/Enam\%20Cara \%20Kurangi\%20Hormon\%20Stres. Diakses 13 Februari 2012.

18. Supriati L. Statistik Nonparametrik (Materi Kuliah Tidak Dipublikasikan). Mata Kuliah Nursing Research I. Malang: Fakultas Kedokteran Universitas Brawijaya. 21 Mei 2012.

19. Wahyuni S. Pengaruh Pemberian Aromaterapi Minyak Atsiri Bunga Mawar terhadap Tingkat Stres Mahasiswa dalam Mengikuti Pembelajaran Klinik di PSIK FK-UNAND Tahap Profesi Tahun 2012. Penelitian. Tidak diterbitkan. Padang: Fakultas Keperawatan Universitas Andalas. 2012.

20. Smeltzer S. Buku Ajar Keperawatan Medikal Bedah Brunner \& Suddarth. Edisi ke-8. Yasmin A (Penerjemah). Jakarta: EGC. 2002. HIm. 545.

21. Leometa $\mathrm{CH}$. Penerimaan Diri Penderita Systemic Lupus Erythematosus (SLE) Usia Dewasa Muda. Skripsi. Tidak diterbitkan. Depok: Fakultas Psikologi Universitas Indonesia. 2007. 